patient identification will be able to provide unduplicative data, particularly in areas with increasing laboratory consolidation. We currently are evaluating such a surveillance effort in Minnesota and believe that this approach is useful and workable.

The increasing problem of antimicrobial resistance will be a major challenge for the medical and public health communities over the next decade. Without the combined and collaborative efforts of private and public medical laboratories, clinicians, pharmaceutical companies, and public health practitioners, the problem of antimicrobial resistance will spread in scope and seriousness at an ever more rapid pace. Given the current available information on the rapid expansion of antimicrobial resistance of a number of important clinical pathogens over the past 5 years, we may well be entering those first days of the "postantibiotic era." Timely and comprehensive public health surveillance for antimicrobial-resistant organ- isms on a national basis is critical if we are to better understand the burden of illness related to these pathogens, find appropriate treatment approaches, detail other interventions to reduce the incidence and prevalence of resistant pathogens in our human and animal populations, and determine the role of vaccine development in addressing this problem.

\section{REFERENCES}

1. American Society for Microbiology. Report of the ASM Task Force on Antibiotic Resistance. Washington, DC: ASM; 1994.

2. Institute of Medicine. Emerging Infections: Microbial Threats to Health in the United States. In: Lederberg, Shope. Oaks, eds. Washington, DC: National Academy Press; 1992:92-101.

3. Paul SM, Finelli L, Crane GL, Spitalny KC. A statewide surveillance system for antimicrobial resistant bacteria: New Jersey. Infect Control and Hosp Epidemiol 1995;16:385-390.

4. Berkelman RL, Bryan RT: Osterholm MT, LeDuc JW, Hughes JM. Infectious disease surveillance: a crumbling foundation. Science $1994 ; 264: 368-370$.

\title{
OSHA's TB Standard To Be Peer-Reviewed
}

\section{by Gina Pugliese, RN, MS Medical News Editor; Michael D. Decker, MD, MPH SHEA Liaison to OSHA}

The Occupational Safety and Health Administration (OSHA) has delayed its proposed tuberculosis standard so that the standard may be peer reviewed in accordance with a requirement in the regulatory reform legislation being considered by Congress. The risk-assessment portion of a standard must show that evidence exists for significant risk of health impairment if existing conditions are not reduced or eliminated.

OSHA announced that the four individuals chosen to review the standard's risk-assessment provisions were George Comstock, professor of epidemiology at Johns Hopkins University; Patricia Siione, deputy chief of the program services branch of CDC's Division of Tuberculosis Elimination; Neil Graham, associate professor of epidemiology at Johns Hopkins University; and Bahjat Qaqish, associate professor of biostatistics at the University of North Carolina. The comments of the panelists will be taken into consideration before the proposed rule is pub lished.
According to the agency, the draft risk assessment and the reviewers'comments will be published in the Federal Register, along with the proposed standard, in October 1995.

OSHA's Deputy Assistant Secretary James W. Stanley acknowledged that the healthcare industry has made considerable progress in addressing concerns about TB transmission in the workplace.

FROM: Bureau of National Affairs. Panel named to review tuberculosis proposal. H ealth Law R eporter May 24, 1995:A12-A13.

\section{FLASH! Late-Breaking News}

\section{by Gina Pugliese, RN, MS Medical News Editor}

On June 7, 1995, OSHA announced that the proposed revised Respiratory Protection Standard will not apply to tuberculosis protection.
Rather, the current Respiratory Protection Standard will govern TB protection until a formal TB standard is adopted. Once final, however, the revised Respiratory Protection Standard will govern all other respiratory exposures (chemical, toxic, etc) in the healthcare industry.
Effective July 10, 1995, NIOSH will begin certifying a new class of respirators (now called $95 \mathrm{~N}$ ) that may be used instead of HEPA for tuberculosis protection. These long-awaited respirators are likely to reach the market by August or September. 